\title{
Kristifor Pantelin
}

\section{Prostorsko urejanje slovenske obale s pomočjo bagranja}

Bagranje,
Ravnanje
s sedimentom,
Plovni kanali,
Zakonodaja
o bagranju,
Slovenska obala
Dredging,
Treatment
of dredged
material,
Navigable
channels,
Legislation
on dredging,
Slovenian coast

Bagranje in ravnanje $s$ sedimentom se $v$ večini primerov obravnava kot tehnologijo, ki omogoča izgradnjo in vzdrževanje plovnih poti. $V$ raziskavi, ki sem jo izdelal $v$ sklopu magistrske naloge, sem želel predstaviti način, kako lahko bagranje pripomore $k$ prostorskemu urejanju slovenske obale. Slovenska obala je relativno kratka in omejena, ob njej so veliki poselitveni interesi. Zaradi tega obstajajo težnje po daljšanju obale s pomočjo nasipavanja oz. ustvarjanja umetnih otokov in polotokov. Velikokrat se nasipava zaradi izgradnje pomolov, za potrebe marin in ostalih pristanišč. Cilj raziskave je bil obrniti ta trend, ki bi se izognil krčenju morskih površin in tako izkoristiti kanale ter razširiti oz. ustvariti nove vodne površine za potrebe gospodarskih dejavnosti ali zaradi varovanja okolja. Da bi to dosegel, je bilo potrebno najprej preučiti zakonodajo ter poiskati ustrezen način za ravnanje z izkopanim sedimentom. Ko smo zagotovili nadaljnje ravnanje $s$ sedimentom, je možno upoštevati bagranje kot pomemben dejavnik pri predlagani prostorski ureditvi slovenske obale.

\section{Uvod}

Slovensko morje se nahaja $\mathrm{v}$ relativno zaprtem Tržaškem zalivu in je razmeroma omejeno, saj dolžina obalne črte znaša $46 \mathrm{~km}$. Kljub temu se na obalnem področju Slovenije nahaja vrsta različnih obmorskih aktivnosti, kot so: koprsko pristanišče, Sečoveljske soline, turizem, ribiška industrija, naravna območja, tri marine in ladjedelnica.

Vse te dejavnosti so razdeljene $\mathrm{v}$ treh obalnih mestih: Koper, Izola in Piran. Ureditev slovenske Istre je posledica potreb iz preteklosti, ko se je skušalo porazdeliti delovna mesta čim bolj enakomerno med tri občine. Poleg tega je bila obalna črta v nekdanji Jugoslaviji veliko daljša, kar je tudi vplivalo na vrsto in način urejanja slovenske obale. Zaradi
Dredging and sediment proceeding is in most cases treated as a technology which makes possible the construction and maintenance of navigable ways. In the research which I made in the masters thesis context, I wanted to present how can dredging contribute to spatial planning of the Slovenian coast, which is relatively short and limited, where big settlement interests are present. For this reason there are aspirations for lengthening the coast with building embankments or making artificial islands and peninsulas. Several times embankments are built on account of the constructions of piers, for marinas and other ports. The aim of the research was to invert this trend, which would avoid the restrictions of sea areas and to make good use of channels and widen or create new water surfaces for economic activities or for environmental safeguard. To attain this, it was necessary at first to study legislation and find an appropriate way of treating dredged material. When further sediment treatment is assured, it is possible to consider dredging as an important factor by the proposed spatial arrangement of the Slovenian coast.

potreb tedanjega gospodarstva je bilo zasutih veliko plitvin in zalivov, kar je vplivalo na krajšanje slovenske obale.

Glede na pomen slovenske obale je smiselno razmišljati o daljšanju obalnega prostora. To je možno narediti na dva načina: z nasipavanjem umetnih otokov in polotokov ali s podaljševanjem obale v kopno. Pri zasipavanju tako zaprtega morja, kot je Tržaški zaliv, se pojavi veliko vprašanj. Ne ve se natančno, kako bi tovrstni posegi vplivali na morski tok ter na populacijo v morju. Velik pomen ima tudi izbira materiala, iz katerega bo obala zgrajena. Še posebno vlogo ima skalomet ali robni del med morjem in kopnim. Poleg tega bi s takimi posegi zmanjšali površino in količino slovenskega morja in $\mathrm{s}$ tem tudi življenjski prostor rib in ostalih 
morskih organizmov. S tem se lahko poslabša položaj ribičev ter drugih poklicev, ki so vezani na morje.

Poleg nasipavanja zaradi človeških dejavnosti je potrebno opozoriti na nanose rek in erozijo tal, ki v morje nanašajo velike količine sedimenta. Naravni nanosi se nenehno odlagajo na morsko dno in tako zmanjšujejo količino slovenskega morja. Zato je smiselno, da se v Sloveniji izognemo dodatnemu nasipavanju in s pomočjo bagranja podaljšujemo obalno črto v notranjost.

Z daljšanjem obale v kopno je možno urejati ustja rek ter mirujoče dele strug, obstoječe in novonastale kanale, zatoke, lagune ter ostale plitvine in nižine. Na tak način se ne posega v morje in obalno črto in s tem se onemogoči, da bi povzročali škodo v morju. Poleg tega se povečuje tudi količina morske vode, kar pomeni boljše pogoje za žive organizme v morju. S širitvijo kanalov in ustij rek pride do mešanja sladke in slane vode, kar obogati življenjski prostor za organizme, ki živijo v obalnem predelu. Poleg tega tak prostor nudi varna zatočišča za plovila ter možnosti za predvsem lokalni vodni promet.

Da bi lahko to počeli, je potrebno predhodno poznati tehnologijo bagranja, zakonodajo, mnenja prebivalstva, ekonomske učinke, lastnosti izkopanega materiala ter vpliv na naravno okolje in dejavnosti $\mathrm{v}$ predvidenem območju. Predvsem pa je potrebno vedeti, kaj je dovoljeno in kaj je možno početi $z$

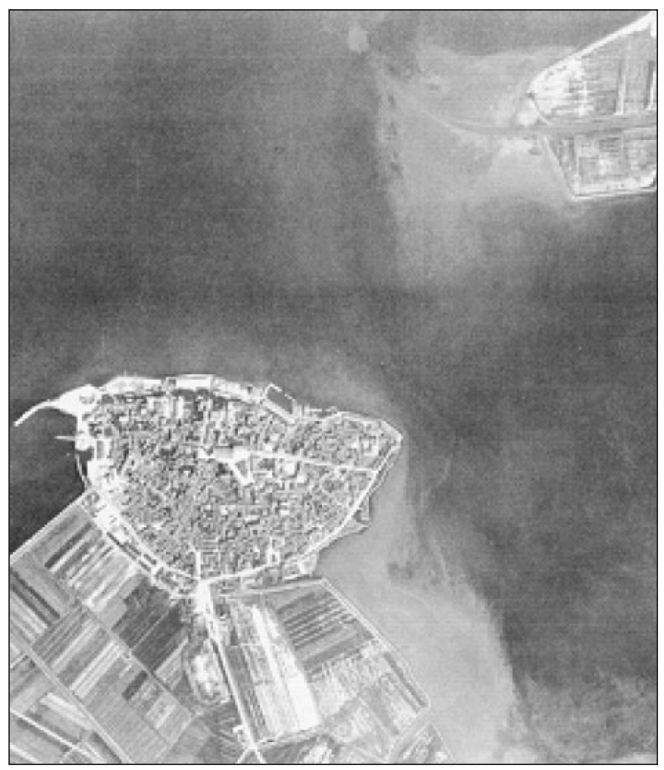

bagranim materialom. V raziskavi sem se ukvarjal predvsem z zakonodajo in možnostmi koristne uporabe sedimenta.
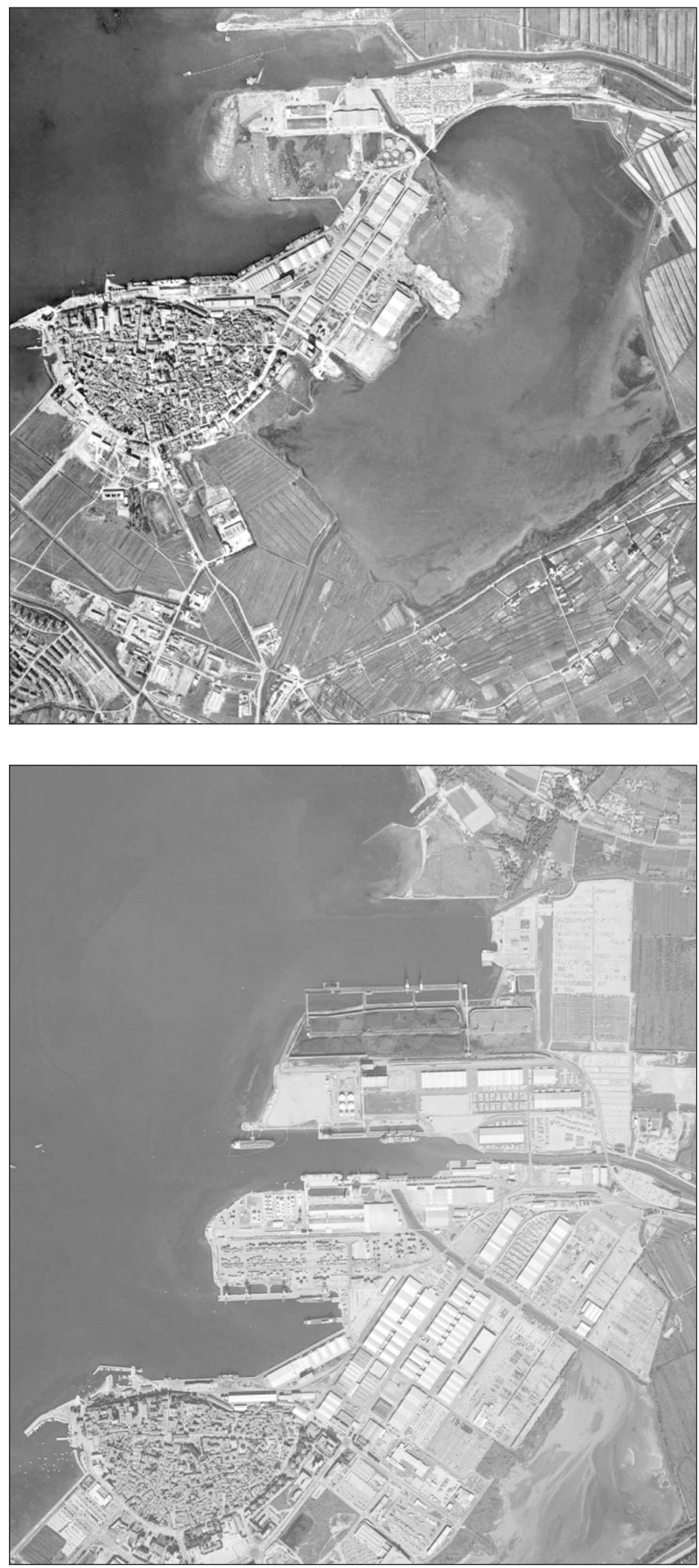

Prevzete slike 1, 2 in 3: Koper od sredine do konca 20. stoletja (Luka Koper, B. I.) 


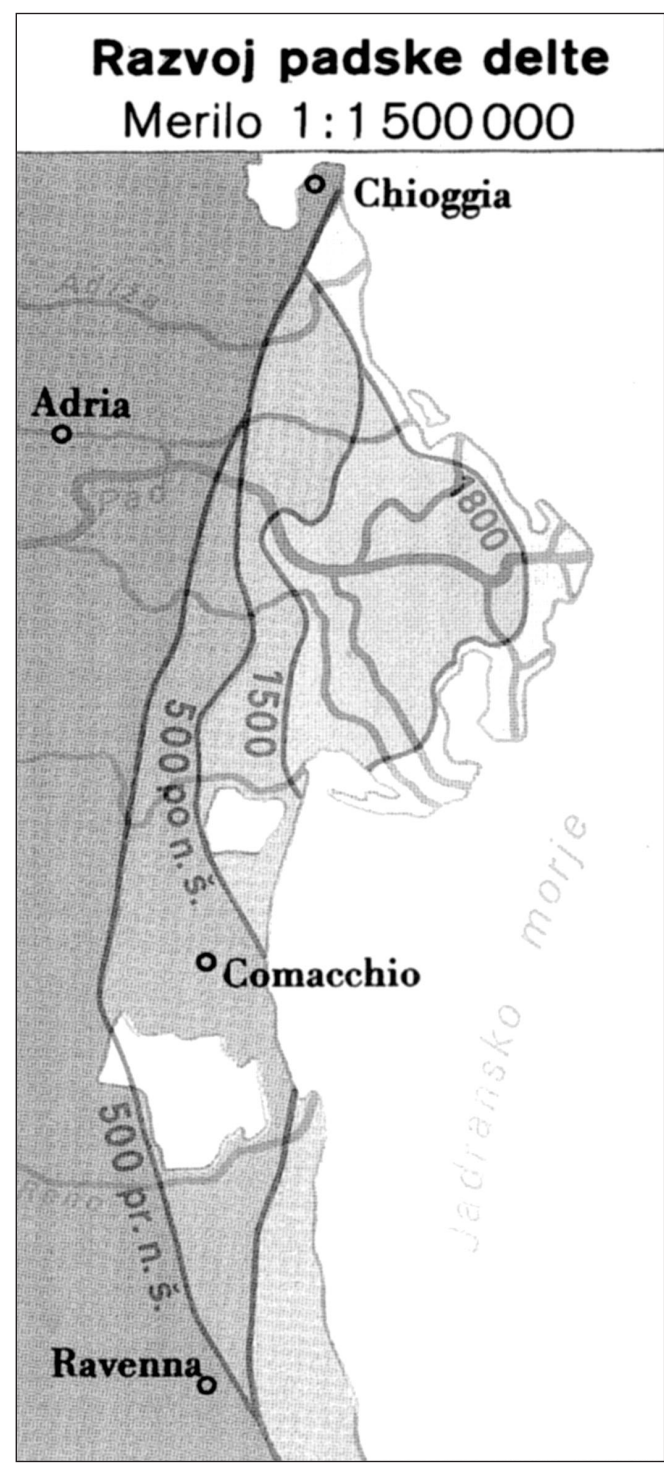

Prevzeta slika 4: Razvoj padske delte (Atlas, 1993)

\section{Predstavitev Bagranja In Odlaganja Sedimenta}

Tako v morju kot v sladkih vodah se srečujemo s sedimentom (muljem), ki se nabira na vodnem dnu. Kopičenje mulja na vodnem dnu je odvisno predvsem od nanosa vodotokov, morskih tokov, erozije ter drugih pojavov. Na območjih, kjer potekajo razne dejavnosti, kot je denimo vodni promet, postane nakopičen sediment moteč in ga je sčasoma treba odstraniti. Pri tem se pojavijo tri vprašanja, in sicer: kako sediment odstraniti, kam ga odložiti (lahko tudi začasno) ter kako ga do deponije transportirati. Tehnologija bagranja je že zelo razvita in v večini primerov odstranjevanje nabranega sedimenta s tehničnega vidika ne predstavlja težav, problem pa se pojavi, ko je treba ta material nekam odložiti.

Bagranje je pobiranje snovi oz. materiala $\mathrm{z}$ vodnega dna ter transport in odlaganje materiala na določeno lokacijo. Tovrsten način se uporablja $z$ namenom urejanja plovnih poti in luških bazenov, vzdrževanja vodotokov zaradi vodarskih potreb, pridobivanja materiala za potrebe gradbeništva, vzdrževanja jezov za potrebe hidroelektrarn ter za melioracijo znotraj vodnih površin. Bagranje se izvaja na morju, rekah, kanalih in jezerih, torej je tovrsten način poglabljanja vodnega dna znan tako $\mathrm{v}$ obmorskih kot tudi $\mathrm{v}$ kontinentalnih državah.

Razvitost bagranja je v svetu na visoki ravni in poznamo različne tehnologije, izbira katere je odvisna predvsem od okoliščin, v katerih se bagranje izvaja. Veliko večji problem od bagranja je odlaganje izkopanega materiala ali sedimenta. Poleg tehničnih omejitev glede transporta in odlaganja sedimenta so veliko bolj pomembne zakonske omejitve, ki urejajo nadaljnje ravnanje s sedimentom.

\section{Zakonodaja}

Kadar govorimo o evropski zakonodaji, se je treba zavedati, da ta ne preklicuje mednarodne zakonodaje, ki so jo ratificirale posamezne države članice EU. Pogosto se zgodi, da pride do trenja med dvema, v takih primerih ima prednost mednarodna zakonodaja. Evropska zakonodaja se ne ukvarja direktno z bagranjem oz. z ravnanjem z bagranim materialom. Kljub temu pa vrsta evropskih direktiv posredno ali neposredno posega na področje ravnanja s sedimentom. Relevantne predpise je možno združiti v tri skupine, in sicer: odpadki, vode in varstvo okolja. Med tremi skupinami je še posebej potrebno področje odpadkov, ki opredeljuje vrsto odpadkov ter določa odnos do ravnanja z bagranim materialom.

Evropska zakonodaja o odpadkih opredeljuje načine ravnanja $z$ odpadki, preprečevanje nastajanja, ponovno uporabo, reciklažo, predelavo ter odlaganje. Opredeljuje tudi, kdaj snov postane odpadek, med katerega Evropska komisija uvršča tudi sediment oz. bagrani material. EuDA (angl. European Dredging Contractors) ima glede sedimenta drugačno stališče in smatra, da je treba sediment obravnavati 
kot naravni resurs in ne kot odpadek (Mink, Dirks, Van Raalte, De Vlieger in Russell, 2006). Postavlja se vprašanje, zakaj je treba snov, ki jo vzameš na eni strani in odložiš na drugi, pri tem pa ima snov isto vlogo kot prej, obravnavati kot odpadek. Vprašanje je še toliko bolj pomembno, ker je večina evropskih držav ratificirala mednarodne konvencije, kot so: Londonska konvencija, konvencija OSPAR, Barcelonska konvencija ipd., ki dopuščajo odlaganje sedimenta v morje. To pomeni, da je evropska zakonodaja relevantna le pri odlaganju sedimenta na kopno.

Tako kot evropska tudi slovenska zakonodaja opredeljuje bagrani sediment kot odpadek, razen izjem. Ravnanje s tovrstnim odpadkom urejajo različni slovenski predpisi, kar pomeni, da v praksi prihaja do različnih tolmačenj oz. do različnih možnosti nadaljnje rabe sedimenta. V kolikor gre za izkope manjšega obsega ali se vnos zemeljskega izkopa vrši skladno s pogoji gradbenega dovoljenja, pristojni slovenski predpis dopušča, da se nadaljnje ravnanje izvaja brez dovoljenj, ki so sicer potrebna za ravnanje $\mathrm{z}$ odpadki. V takih primerih je potrebno izdelati "presojo vplivov na okolje « (PVO). Predpis, ki ureja PVO, opredeljuje tudi oprostitve, med katerimi želim posebej poudariti dva primera, in sicer: poglabljanje morskega dna na prometnih poteh plovil ter primer, ko gre za vzdrževanje vodotokov iz preventivnih razlogov ali zaradi varnosti pred visokimi vodami. V praksi PVO izdela pooblaščena organizacija, ki lahko presojo naredi glede na enega izmed zgoraj navedenih predpisov ali na podlagi splošno znanih podatkov. Iz tega sledi, da so merila za odlaganje sedimenta precej nejasna. Ta situacija $v$ praksi ne povzroča večjih težav, saj pristojne državne službe pogosto svetujejo izvajalcem, kako in po katerem predpisu ravnati z izkopanim materialom, ki je lahko iz kopnega ali iz vodnega dna. Težava nastane, ko se želi dolgoročno zastaviti način ravnanja s sedimentom in določiti možnosti, ki jih zakonodaja dopušča ali odreja.

V novih članicah EU, kot je Slovenija, pa prihaja tudi do napačnega razumevanja vsebine evropske zakonodaje. Primer za to je Škocjanski zatok v bližini koprskega pristanišča. Zatok je $z$ morjem povezan le preko kanala in II. luškega bazena. Zatok se je zaradi širitve pristanišča in mesta $z$ leti samo krčil (glej slike 1, 2 in 3). Naravovarstveniki so zaščitili zatok in ga preuredili v brakično laguno. Gre dejansko za umetno ustvarjen habitat, ki se nahaja tik ob edinem slovenskem pristanišču in ob gospodarsko najbolj razvitem delu mesta. Direktiva 92/43/EGS o ohranjanju naravnih habitatov in Direktiva 79/409//EGS o prostoživečih pticah v določenih primerih dopuščata izdelavo nadomestnih naravnih območij oz. umetno ustvarjanje habitatov. Večinoma gre za primere, ko gre za dejavnosti širšega javnega interesa (pristanišča ipd.), ki posegajo $\mathrm{v}$ naravno okolje. V takih primerih je možno zagotoviti nadomestno območje. V primeru Škocjanskega zatoka pa je zadeva obratna. Degradiran morski zaliv bodo tako dodatno degradirali in zapirali dotok slane vode $\mathrm{z}$ zapornicami. Še huje je to, da kanal do morja poteka skozi II. luški bazen, kjer se pretovarja tekoče tovore, kot so nafta in kisline, poleg tega pa se $\mathrm{v}$ isti bazen izlivajo le mehansko prečiščene fekalne vode iz Kopra in kmalu še iz Izole. Gre za veliko nasprotje, saj se ustvarja umetno zaščiten habitat v ostanku morja, po katerem se je nekoč plulo, danes pa se nahaja na sredi gospodarsko pomembnega območja. Poleg tega ima to območje veliko ekonomsko vrednost, še bolj pomembno pa je, da je za državo s $46 \mathrm{~km}$ obale pomemben vsak meter obale in morja.

\section{Bagranje v slovenskem morju}

Največ bagranja se izvaja na območju koprskega pristanišča. V procesu izgradnje pristanišča so izkopani material uporabljali za nasipavanje pomolov in zaledja koprske luke. $\mathrm{Na}$ začetku je šlo za tradicionalne načine izkopa, vendar so kmalu začeli uporabljati rezalno-sesalno tehnologijo bagranja.

Odlaganje sedimenta na kopno z vidika zakonodaje ni sporno, saj gre za neonesnažen sediment, težava je $\mathrm{v}$ tem, da zmanjkuje ustreznih lokacij za odlaganje sedimenta. Zato je bilo potrebno preveriti možnosti, kaj lahko počnemo z muljem oz. sipkim sedimentom. V Sloveniji je zelo malo ustreznih lokacij, kjer bi lahko sediment odlagali z namenom prekrivanja zemljišč, zato sem se odločil preveriti druge možnosti koristne oz. ponovne uporabe sedimenta. Možno je uporabiti sediment za polnjenje vreč oz. cevi, ki se uporabijo za utrjevanje brežin ali podvodnih 
brežin, vendar je tovrstna raba primerna za manjše količine sedimenta.

Zato sem iskal druge rešitve, ki bi dolgoročno rešile problem nadaljnjega ravnanja s sedimentom. Na Japonskem so poskusili obdelovati sediment $z$ dodajanjem različnih aditivov in prišli do zanimivih rezultatov (Demars, Richardson, Yong in Chaney, 1995). Kljub temu je uporabnost stisnjenega sedimenta omejena. Podobne obdelave s sedimentom so prisotne predvsem tam, kjer je leta onesnažen. Zaradi tega je belgijska družba Solvay razvila t. i. tehnologijo »Novosol « za ravnanje $z$ onesnaženim sedimentom. Tudi $v$ Benetkah so se v sklopu projekta TRASED lotili pilotskega projekta in onesnažen sediment uporabili za proizvodno opek ter poskusno odlaganje $\mathrm{v}$ nemške rudnike. Specifika tovrstnih projektov je, da so taka ravnanja izredno draga in primerna za ravnanje $\mathrm{z}$ onesnaženim sedimentom, kjer so stroški ravnanja $v$ vsakem primeru visoki. Slovenija oz. slovenska obala nima težav z onesnaženim sedimentom, ampak ima prostorske

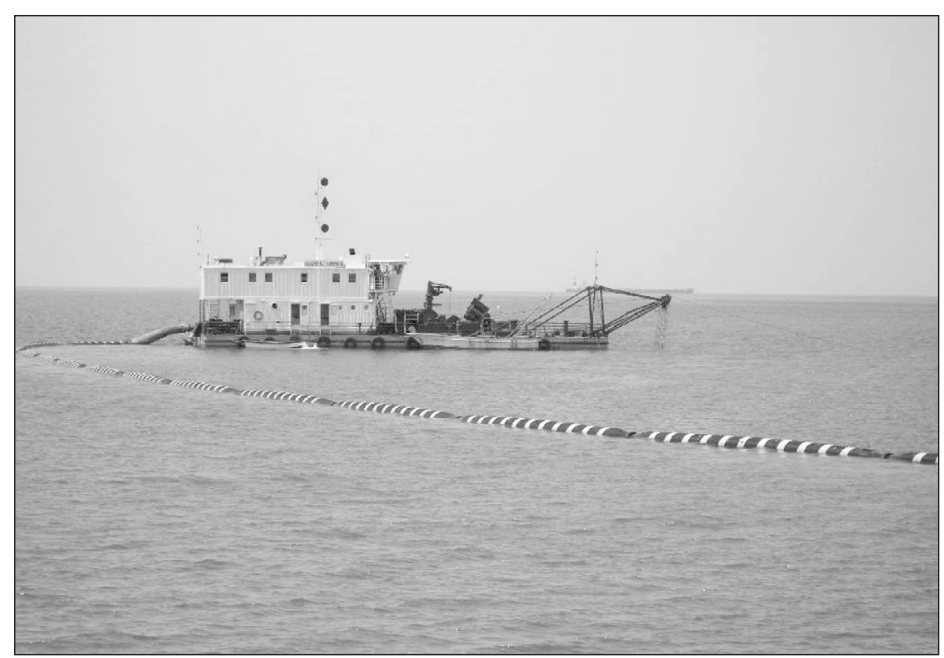

Avtorska slika 1: Bager Martin Krpan

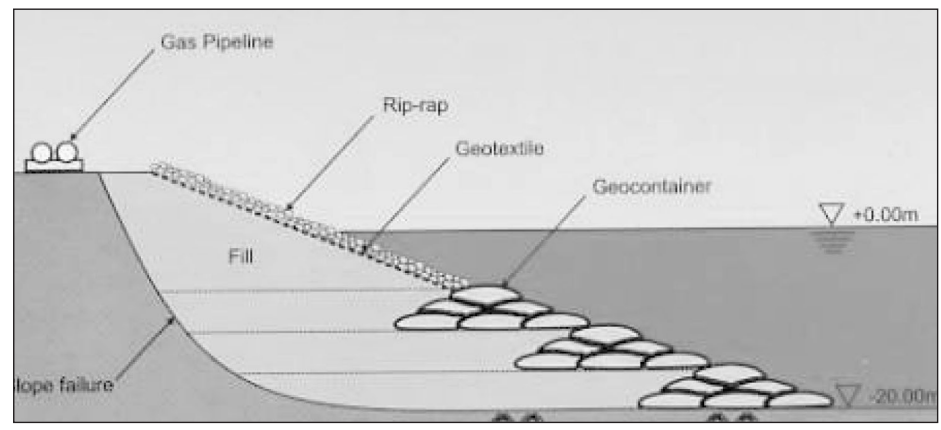

Prevzeta slika 5: Izdelava brežine pod valolomom (Geocontainer, 2006, str. 2) omejitve. Italijanska družba Monfalcone Ambiente iz Tržiča (Monfalcone) izvaja pilotski projekt ravnanja $\mathrm{z}$ neonesnaženim sedimentom oz. sedimentom, ki ni nevaren odpadek. Sedimentu odstranijo kloride, torej sol in nevarne primesi, kot so težke kovine. Prod in pesek uporabijo v gradbeništvu, mulj pa za ustvarjanje plaž in nadomestnih nasipov.

Glede na čistost sedimenta $\mathrm{v}$ slovenskem morju je tovrstna obdelava ustrezna tudi za slovenske potrebe, vendar kam odložiti prečiščeni mulj! Ob obisku cementarne Salonit Anhovo v Sloveniji sem spoznal, da uporabljajo lapor kot surovino za proizvodnjo cementa (klinker). Upoštevajoč, da je sestava terena na slovenski obali predvsem iz laporja, sem domneval, da ima sediment podobne lastnosti. Da bi lahko preizkusil uporabnost sedimenta, sem ga predhodno opral v sladki vodi in tako iz njega odstranil morsko sol. Opran vzorec so analizirali v laboratoriju cementarne Salonit Anhovo in ugotovili, da lahko uporabijo 200 ton opranega sedimenta na teden. Z boljšo predobdelavo sedimenta, kot je na primer v Tržiču (več odstranjenih kloridov in težkih kovin), je možno to količino povečati tudi za 10-krat. Obdelan sediment je za cementarno surovina in ga je pripravljena prevzemati brez plačila. Z 2.000 tonami sedimenta na teden bi lahko uporabili celotno količino, ki se v povprečju nakoplje $\mathrm{v}$ koprskem pristanišču. V kolikor upoštevamo potencial vseh cementarn v Sloveniji, pridemo do zaključka, da lahko uporabimo celotno količino sedimenta, bagranega $\mathrm{v}$ slovenskem morju, tudi ob intenzivnejšem bagranju. S tem bi zagotovili koristno rabo sedimenta znotraj Slovenije brez čezmejnega pošiljanja odpadkov.

\section{Urejanje slovenske obale s pomočjo tehnologije bagranja}

Z načrtno izdelanim procesom ravnanja s sedimentom in prostorsko politiko Slovenija lahko resno razmišlja o podaljševanju svoje obale. Z izdelano rešitvijo ravnanja s sedimentom lahko razmišlja o izdelavi kanalov in podobnih plovnih poti globoko v kopno. Po izkušnjah iz Italije so kanali ustrezni za različne morske in obmorske dejavnosti. Večinoma so kanali že obstoječi in jih je treba za 
plovbo le nekoliko razširiti in poglobiti. Nudijo varno zavetišče čolnom in ladjam brez izgradnje velikih valobranov in podobne infrastrukture. Na tak način se ne uničuje naravne obalne črte ter ne zmanjšuje količine morja, ampak obratno, saj se količina morske vode tako poveča, kar je za slovensko morje lahko le pozitivno. Z ureditvijo kanalov je možno urediti tudi sprehajalne in rekreacijske poti ob njih. Lahko predstavljajo neke vrste naravne pregrade med bivalnimi in gospodarskimi območji, zato sem predlagal, da je koprsko

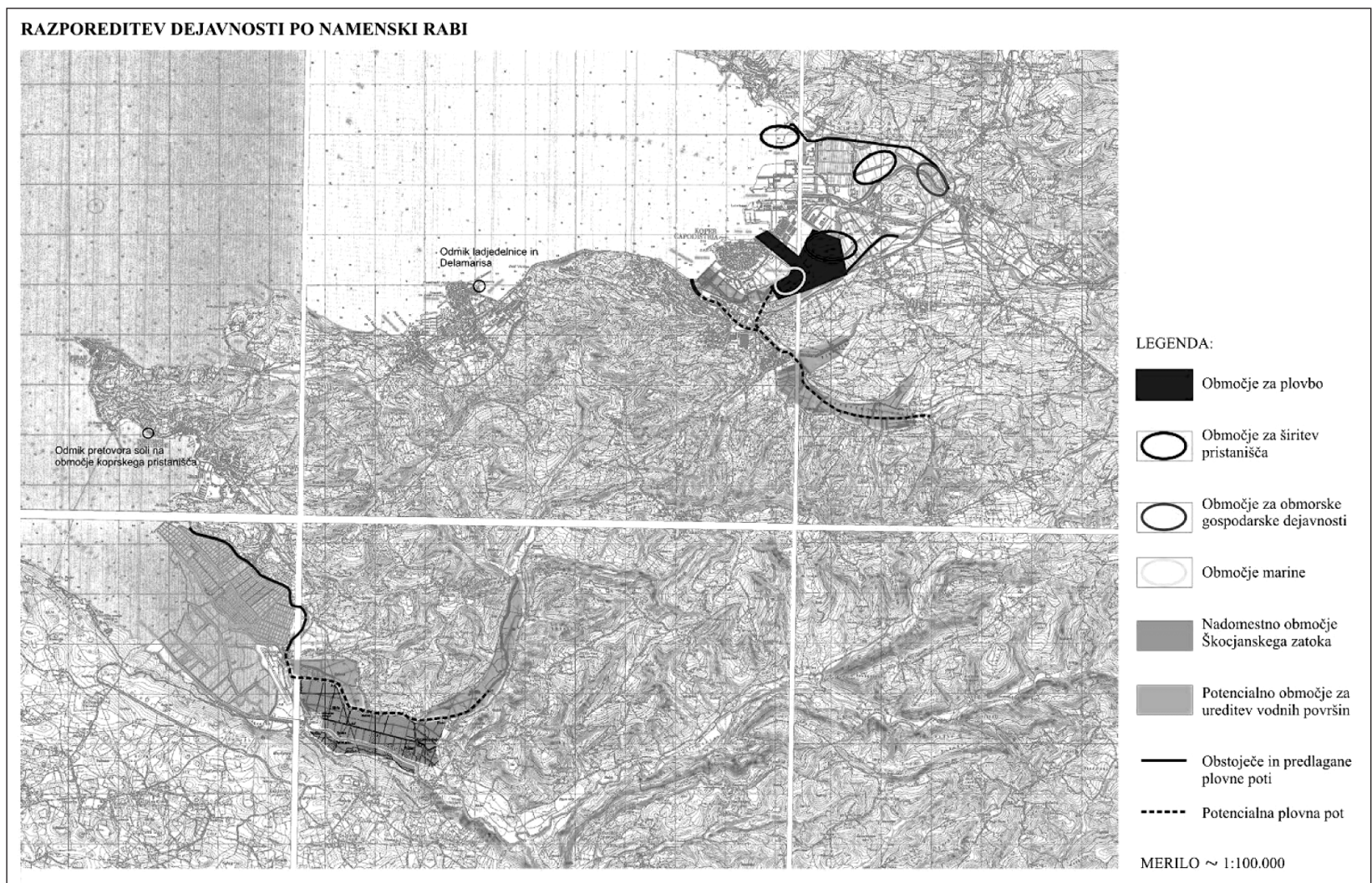

Avtorska slika 2: Razporeditev dejavnosti po namenski rabi

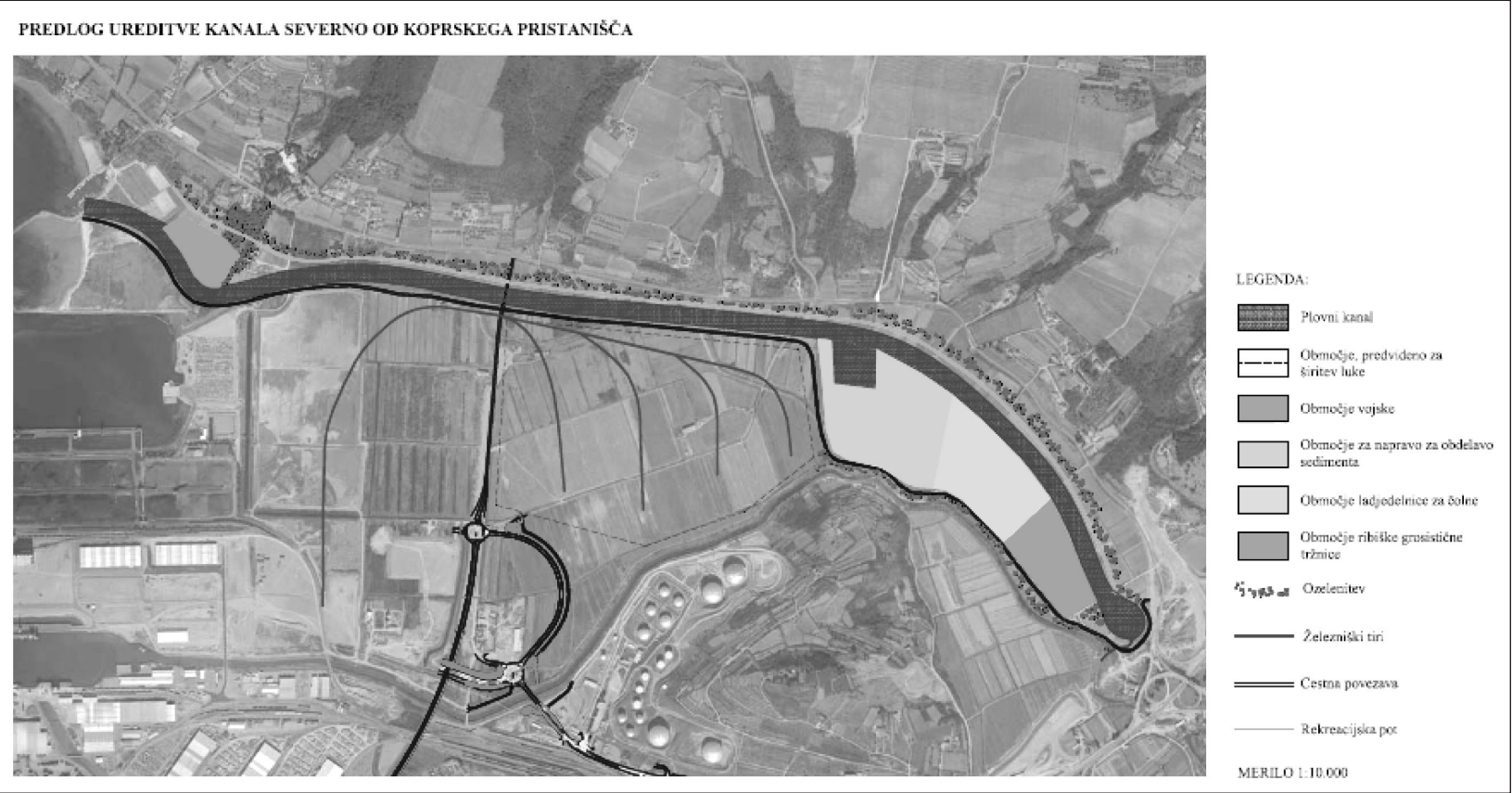

Avtorska slika 3: Ureditev kanala severno od koprskega pristanišča 
pristanišče od bivalnih območij na severu in jugu ločeno s kanaloma.

V toku zgodovine so na slovenski obali zasuli velika območja, ki jih je nekoč prekrivalo morje. Ne pozabimo na dejstvo, da sta bila Koper in Izola otoka, ter na številne soline, ki so sčasoma postale obdelovalna polja. V novejšem obdobju so veliko obale pozidali. Smiselno bi bilo obrniti ta trend in ohraniti ali morda celo "ponovno ustvariti « čim več morja. S tem se kaže odnos naše države do morja ter pomorske kulture. Z izgubljanjem morja ne izgubljamo samo plaž, ribištva in marikulture, ampak tudi naravno dediščino, delovna mesta in obmorsko kulturo. Pomemben dejavnik pri tem predstavlja stroka prostorskega načrtovanja oz. povezovanje različnih strok. S skupnim dogovorom med različnimi strokami je možno zagotoviti varstvo narave in trajnostni razvoj ter se izogniti pri-

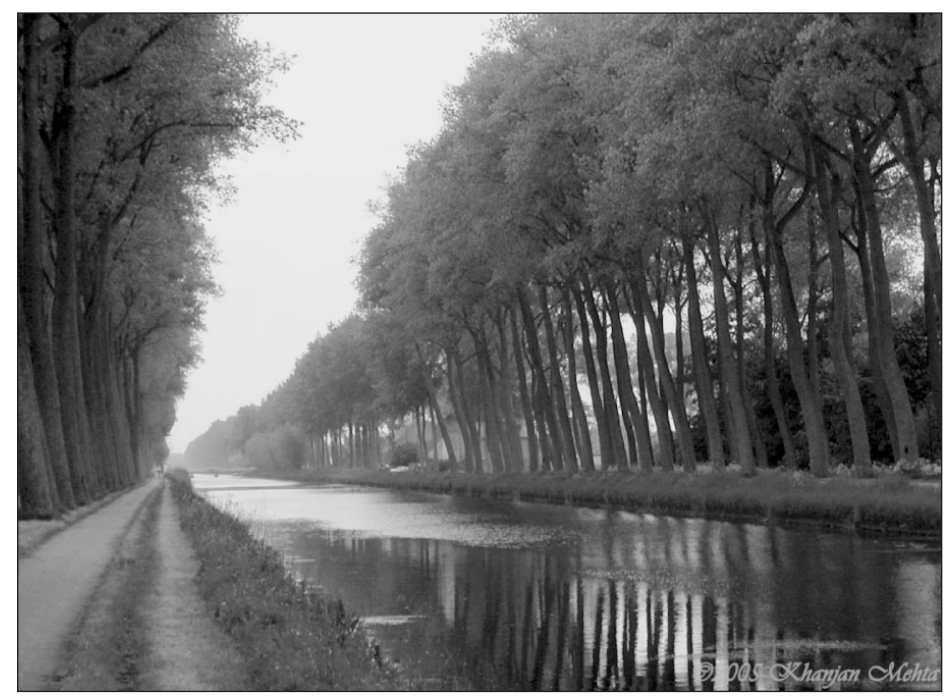

Prevzeta slika 6: Plovni kanal na podeželju (EuDA, 2006)

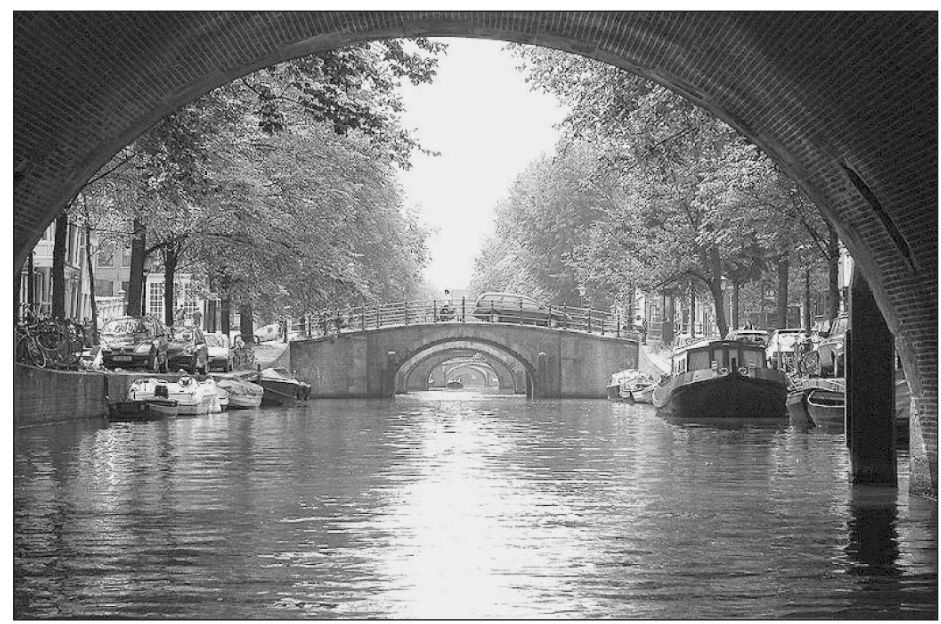

Prevzeta slika 7: Plovni kanal v mestu (EuDA, 2006) tiskom določenih interesnih skupin, ki nimajo izključne legitimne pravice v procesu gospodarjenja $\mathrm{z}$ morjem in slovensko obalo.

Severni razbremenilnik reke Rižane je možno zelo dobro izkoristiti. Lokacija med kanalom in Srminom je primerna za postavitev mandrača za delovna plovila z napravo za obdelavo sedimenta, poleg katere lahko najde prostor še katera druga gospodarska dejavnost, kot je denimo naprava za obdelavo sedimenta, ladjedelnica za čolne in podobno. Preostali del kanala bi bil večinoma namenjen priveznim mestom za čolne ter rekreacijskim površinam. Ker je kanal namenjen pretežno dejavnostim za preživljanje prostega časa in predstavlja zeleno mejo med pristaniščem in bivalnim območjem, obstaja velika verjetnost, da bi prebivalci tovrstno rešitev dobro sprejeli. Poleg tega nudi možnost tudi gospodarstvu in ni videti razlogov, da bi kanal predstavljal moteč dejavnik v varovanju narave. Podobno je s kanalom na severni strani Sečoveljskih solin, ki bi povezal vas Sečovlje in morje. Tu sicer niso predvidena območja za gospodarsko dejavnost, zato pa je lahko del prostora namenjen ohranjanju narave. Kot veliko bolj problematično zamisel vidim selitev Škocjanskega zatoka na območje za Sečoveljskimi solinami. Škocjanski zatok je naravni rezervat in sodi v območje $\mathrm{Na}$ ture 2000. Ustanove, ki skrbijo zanj, bi stežka dovolile kaj podobnega. Poleg tega bi to pomenilo velik finančni izdatek. Ne glede na navedeno bo Slovenija morala sprejeti strategijo razvoja slovenske obale, v kateri bo treba določiti, kaj bo varovala in kaj bo namenila razvoju. Od strategije bo odvisna tudi usoda tako specifičnih skupin ljudi, kot so ribiči in ladjedelničarji. Prvi so odvisni od količine in kakovosti morja, drugi od pogojev za delo in naročil. Primer slovenske družbe Seaway, ki je izbrala lokacijo v italijanskem Tržiču za izgradnjo ladjedelnice za turistične čolne, vsekakor ne govori v prid našim ladjedelničarjem. Škoda je, da se kapital in znanje selita $v$ druge države, ko bi ju lahko ohranjali pri nas. Ni nujno, da se pri nas izdelujejo čezoceanke, možno se je specializirati za manjša plovila in dosegati visoko kakovost, kar je tudi najbolj dobičkonosno.

Z ustreznim načinom ravnanja s sedimentom se odpirajo nove možnosti pri urejanju prostora. Vodne površine nudijo veliko koristi in če so utrjene, imajo velik estetski pomen in nudijo različne gospodarske in športnorekreacijske 
možnosti. Bagranje in ravnanje s sedimentom sta dva pomembna dejavnika pri urejanju vodnih površin in s tem pomemben dejavnik prostorskega urejanja.

mag. Kristifor Pantelin, univ. dipl. inž. prom.

Luka Koper INPO, d. o. o.

E-pošta: kristifor.pantelin@luka-kp.si

\section{Viri In Literatura}

A Marine Strategy to save Europe's seas and oceans (2007) Evropska komisija. http://ec.europa.eu/environment/water/marine/index_en.htm (19.4.2007)

Bizilj, P. 2003. Poročilo o geotehničnih raziskavah na območju severozahodnega dela pomola II, v podaljšku obale TRT2, v Luki Koper. Ljubljana, Geoinženiring: $11 \mathrm{str}$

Demars, K. R., Richardson, G. N., Yong, R. N. in Chaney R. C. 1995. Dredging, Remediation and Containment of Contaminated Sediments. Philadelphia, ASTM: $333 \mathrm{str}$

Direktiva Evropskega parlamenta in Sveta 2000/60/ES z dne 23. oktobra 2000 o določitvi okvira za ukrepe Skupnosti na področju vodne politike (UL L št. 327 z dne 22. 12. 2000)

Direktiva Sveta 1999/31/ES z dne 26. aprila 1999 o odlaganju odpadkov na odlagališčih (UL št. 182 z dne 16. 7. 1999)

Direktiva Sveta 92/43/EGS z dne 21. maja 1992 o ohranjanju naravnih habitatov ter prosto živečih živalskih in rastlinskih vrst (UL št. 206 z dne 22. 7. 1992)

Direktiva Sveta z dne 2. aprila 1979 o ohranjanju prosto živečih ptic (79/409/EGS) (UL št. 103 z dne 25. 4. 1979)

EuDA (European Dredging Association). http://www.european-dredging.info/ab6.html (27. 11. 2006)

Geister, I. (2006) Popotovanje od Pirana do Ankarana. Naravopisni esej. Koper, Zavod za favnistiko Koper, 95 str.

Geocontainer

http://www.ntanet.it/central.php?id_selezionata (12. 10. 2006)

Khan, A. (2004) Achieving Sustainability through Legislation, Public Involvement and Training. Terra et Aqua 95, str. 3-10

Luka Koper. http://www.luka-kp.si (10. 1. 2007)
Mariani, M. (1998) Le procedure di recupero dei rifiut non pericolosi - DM 5 Febbraio 1998: simpozij. http://www.ecos.it/ambiente/convegni/senigallia/mariani.htm (17. 1. 2007)

Mink, F., Dirks W., Van-Raalte, G., De-Vlieger, H., Russell, M. (2006) Impact of European Union environmental law on dredging. Terra et Aqua 104, str. 3-10

Pogačnik, A. (2000) Urejanje prostora za tretje tisočletje. Ljubljana, Študentska založba: 178 str.

Poročilo o preizkusu sedimenta. (2005) Koper: Zavod za zdravstveno varstvo Koper: 12 str.

Pravilnik o obremenjevanju tal z vnašanjem odpadkov. Uradni list RS, št. 3/2003 in 44/2003

Pravilnik o ravnanju $z$ odpadki. Uradni list RS, št 84/1998, 45/2000, 20/2001 in 13/2003

Šajn, R. (1999) Geokemične lastnosti urbanih sedimentov na ozemlju Slovenije. Ljubljana, Geološki zavod Slovenije: 7 str.

TRASED: TRAsferimento delle tecnologie e migliori pratiche di gestione dei SEDimenti dragati tra i Porti $\mathrm{d}$ Venezia e Koper. (2006) Projekt Interreg III A Italija Slovenija. Venezia, Autorità Portuale di Venezia. Koper, Luka Koper: 79 str.

Tomić, B. (1982) Bagerska delatnost u Jugoslaviji. Beograd, IRO »Građevinska knjiga«. 257 str.

Upravljanje s sistemom za zbiranje blata iz bagranja. (2006) Tržič, Monfalcone ambiente: 6 str.

Uredba o Krajinskem parku Sečoveljske soline. Uradni list RS, št 29/2001

Uredba o mejnih vrednostih vnosa nevarnih snovi in gnojil v tla. Uradni list RS, št. 84/2005

Uredba o vrstah posegov $v$ okolje, za katere je treba izvesti presojo vplivov na okolje. Uradni list RS, št. $78 / 2006$

Zakon o ratifikaciji Konvencije o varstvu Sredozemskega morja pred onesnaževanjem, protokola o preprečevanju onesnaženja Sredozemskega morja zaradi potapljanja odpadkov in drugih materialov $z$ ladij in letal ter protokola o sodelovanju $v$ boju zoper onesnaženje Sredozemskega morja $z$ nafto in drugimi škodljivimi snovmi v primeru nezgode. Uradni list SFRJ-MP, št. 12/1977 in Uradni list RS-MP, št. 26/2002

Zakon o ratifikaciji Protokola 1996 h Konvenciji o preprečevanju onesnaženja morja z odpadnimi in drugimi snovmi, 1972 (M96KPOM). Uradni list RS, št. 10/2005 Zrnić, P. 1979. (Tehničar) Gradevinski priručnik 5. Beograd, Gradevinska knjiga: 1156 str. 